GRASAS Y ACEITES 71 (4)

October-December 2020, e387

ISSN-L: 0017-3495

https://doi.org/10.3989/gya.1028192

\title{
Physicochemical characterization and oxidative stability of microencapsulated edible sacha inchi seed oil by spray drying
}

\author{
L. Landoni ${ }^{\mathrm{a}}$, R. Alarcon ${ }^{\mathrm{b}}$, L. Vilca ${ }^{\mathrm{b}}$, N. Chasquibol ${ }^{\mathrm{b}}$, M.C. Pérez-Camino ${ }^{\mathrm{c}}$ and G. Gallardo ${ }^{\mathrm{a}, \bigotimes}$
}

${ }^{a}$ National Institute of Industrial Technology, INTI- Av. Gral Paz 5445, San Martín, Buenos Aires, Argentina.

${ }^{b}$ Center of Studies and Innovation of Functional Foods (CEIAF)-Faculty of Industrial Engineering, Institute of Scientific Research, IDIC, University of Lima, Avda. Javier Prado Este, 4600 Surco, Lima 33-Peru.

${ }^{c}$ Department of Characterization and Quality of Lipids, Instituto de la Grasa- CSIC, Ctra. Utrera km 1, Bg 46, E-41013 Sevilla, Spain.

${ }^{凶}$ Corresponding author: ggallardo@inti.gob.ar

Submitted: 23 October 2019; Accepted: 03 December 2019; Published online: 3 November 2020

SUMMARY: The aim of this work was to obtain sacha inchi oil (SIO) microcapsules from two different species, Plukenetia volubilis L. (SIVO) and Plukenetia huayllabambana L. (SIHO), using different biopolymers as wall materials and spray drying technology. The physicochemical characteristics such as encapsulation efficiency, particle size, morphology and oxidative stability were analyzed in order to select the best formulation that could potentially be used as an ingredient in the development of functional food. Bulk SIO and four formulations were tested for each oil ecotype, using different encapsulating agents: maltodextrin (MD), Arabic gum (AG), whey protein concentrate (WPC) and modified starch HI-CAP ${ }^{\mathbb{B}}-100(\mathrm{H})$. Microcapsules made of $\mathrm{H}$ presented the highest oxidative stability and encapsulation efficiency compared to AG, AG:MD or AG:MD:WPC formulations.

KEYWORDS: Microencapsulation; Oxidative Stability; Sacha inchi; Spray drying

RESUMEN: Caracterización fisicoquímica y estabilidad oxidativa de aceites comestibles de semillas de sacha inchi microencapsulados y secados por aspersión. El objetivo de este trabajo fue obtener microcápsulas de dos especies de aceite de sacha inchi (SIO), Plukenetia volubilis L. (SIVO) y Plukenetia huayllabambana L. (SIHO), utilizando diferentes biopolímeros como materiales de pared y la tecnología de secado por aspersión. Se analizaron tanto las características fisicoquímicas como la eficiencia de encapsulación, el tamaño de partícula, la morfología y la estabilidad oxidativa para seleccionar la mejor formulación que podría utilizarse como ingrediente en el desarrollo de alimentos funcionales. Se analizaron los aceites y cuatro formulaciones para cada ecotipo, usando diferentes agentes encapsulantes: maltodextrina (MD), goma Arábiga (AG), concentrado proteico de lactosuero (WPC) y almidón modificado HI-CAP ${ }^{\circledR}-100(\mathrm{H})$. Las microcápsulas hechas con $\mathrm{H}$ presentaron la mayor estabilidad oxidativa y eficiencia de encapsulación en comparación con las formulaciones: AG; AG:MD o AG:MD:WPC.

PALABRAS CLAVE: Estabilidad oxidativa; Microencapsulación; Sacha inchi; Secado por aspersión

ORCID ID: Landoni L https://orcid.org/0000-0003-4356-3447, Alarcon R https://orcid.org/0000-0003-3315-9467, Vilca L https://orcid.org/0000-0002-0157-1695, Chasquibol N https://orcid.org/0000-0002-9275-2060, Pérez-Camino MC https://orcid.org/0000-0001-7652-9582, Gallardo G https://orcid.org/0000-0003-1426-8430

Citation/Cómo citar este artículo: Landoni L, Alarcón R, Vilca L, Chasquibol N, Pérez-Camino MC, Gallardo G. 2020. Physicochemical characterization and oxidative stability of microencapsulated edible sacha inchi seed oil by spray drying. Grasas Aceites 71 (4), e387. https://doi.org/10.3989/gya.1028192

Copyright: (C2020 CSIC. This is an open-access article distributed under the terms of the Creative Commons Attribution 4.0 International (CC BY 4.0) License. 


\section{INTRODUCTION}

Since ancient times, the inhabitants of the Andean region have used native crops (fruits, seeds and tubers) for their nutritional and medicinal properties. Native crops have gained worldwide attention due to the wide range of nutrients and phytochemicals they possess (Campos et al., 2018). Within this group, the fruit of sacha inchi or "Inca's nut" deserves mentioning. This crop is from the Amazon region and belongs to the genus Plukenetia, with five identified species: $P$. volubilis (species that is currently widely marketed), P. brachybotrya, P. polyadenia, $P$. loretensis and recently $P$. huayllabambana (Rodríguez et al., 2010).

There is a current tendency towards the consumption of foods that both satisfy the basic needs of consumers and provide essential nutrients (those that cannot be synthesized by the human body). Among this group, the polyunsaturated fatty acids (PUFAs) of the $\omega-3$ family stand out, and involve various vital functions (Delgado-Lista et al., 2012). Within this fatty acid family, we can mention eicosapentaenoic acid (EPA, C20:5), docosahexaenoic acid (DHA, C22:6) and $\alpha$-linolenic acid (ALA, C18:3), which is a precursor of the first two (Barceló-Coblijn and Murphy, 2009).

$P$. huayllabambana, like $P$. volubilis, is considered an important source of oil and protein of good nutritional quality. In recent years commercial exploitation of the P. huayllabambana species has been explored because the seeds of this ecotype have a higher oil content compared to the seeds of P. volubilis ( $44-54 \%$ vs. $35-49 \%$, respectively), and also present a higher content of $\alpha$-linolenic acid (51\% vs 48\%) (Chasquibol et al., 2014, TrianaMaldonado et al., 2017).

To protect PUFAs from environmental factors such as light, air or humidity and due to the high susceptibility to oxidation based on the chemical structure of $\omega-3$ acids, microencapsulation arises as a solution to delay or inhibit their deterioration (Cholewski et al., 2018). In this methodology, an oil-in-water emulsion is dried, using different biopolymers (gums, fibers, proteins or carbohydrates) as wall materials. (Carneiro et al., 2013, Aberkane et al., 2014).

According to Gous and Park (2005), an ideal coating material should exhibit good rheological properties at high concentrations and easy workability during encapsulation. Also, the coating materials should have the ability to disperse or emulsify the active material and stabilize the emulsion produced. Moreover, they must not react with the material to be encapsulated during processing and prolonged storage. They must have the capacity for sealing and holding the active material within their structure during processing or storage, and the ability to completely release any materials including the solvent used during the process of encapsulation under drying or other desolventization conditions. The coating materials should provide maximum protection to the active material against environmental conditions (e.g., oxygen, heat, light, humidity). They should be soluble in solvents accepted in the food industry (e.g., water, ethanol) chemically nonreactive with the active core materials and finally inexpensive, with food-grade status. All these features are practically impossible to be achieve by a single carrier, so in practice, combinations of two or more materials are frequently used (Silva et al., 2013).

Carbohydrates are mostly used as encapsulating agents, especially for their ability to retain volatiles. Maltodextrins, products of starch hydrolysis, are commonly used as a wall material in the microencapsulation of food ingredients (Gharsallaoui, et al., 2007) because they offer several advantages like neutral taste and aroma, low viscosity at high percentages of solids and good protection against oxidation of the core phase, as well as relatively low cost. However, this type of material does not display good emulsifying capacity. Gums are used to modify the texture of certain foods, encapsulating agents, emulsion stabilizers and crystallization controllers. Historically, Arabic gum has been the encapsulating agent most frequently used due to its versatility, good solubility, low viscosity at high concentrations and very good emulsifying properties associated with its protein moiety and the polysaccharide backbone (Hoseini et al., 2015, Gabas et al., 2007.). Some n-octenylsuccinate derivatized (n-OSA) starches have also been successfully used as wall materials. The introduction of some side chains of lipophilic succinic acid results in modified starches with good emulsifying properties which promote good volatile retention and higher encapsulation efficiency. Proteins are important encapsulating agents due to their emulsifying properties, hydration, gelling and retention of oils and aromas (Salami et al., 2010, Carneiro et al., 2013).

The aim of this work was to compare the physicochemical characteristics and oxidative stability of both SIO species SIHO and SIVO microencapsulated with different wall materials in order to select the best formulation for the development of functional food and to promote communities where sacha inchi seeds are abundant. The microcapsules were characterized in terms of encapsulation efficiency, moisture content, particle size, morphology and oxidative stability.

\section{MATERIALS AND METHODS}

\subsection{Materials}

Sacha Inchi seeds from the species P. huayllabambana grow mainly in the province of Rodríguez de Mendoza, Department of Amazonas and the 
ecotype $P$. volubilis grows in the San Martín region of Peru. Cold-pressed oils from SIH and SIV seeds were obtained in the Oils and Functional Foods Laboratory of the Center of Studies and Innovation of Functional Foods (CEIAF) at the Universidad de Lima (Peru). Their compositions were in agreement with the specified requirement of the technical regulation of Peru (NTP) for extra virgin SIOs, where the acidity value must be $<1 \%$, the tocopherols $>1900 \mathrm{ppm}$ and the fatty acid composition depends on the variety. Thus, the SIHO must have a percentage of oleic acid $>7.9 \%$, linoleic $>24.0 \%$ and linolenic $>55.0 \%$. For SIVO, oleic acid was $>8.9 \%$, linoleic acid $>32.1 \%$ and linolenic acid $>$ $44.7 \%$. The oils were stored at $-15^{\circ} \mathrm{C}$ and protected from light until use.

MD, AG and WPC with $80 \%$ protein content were acquired from Frutarom, Peru S.A., and $\mathrm{H}$ from Ingredion, Argentina. Ultrapure water with $0,04 \mu \mathrm{S} / \mathrm{cm}$ was used for emulsion formation. For the physicochemical analysis, ethyl ether, deionized water, chloroform, glacial acetic acid, $\mathrm{Na}_{2} \mathrm{~S}_{2} \mathrm{O}_{3}$ (all analytical grade) and soluble potato powder starch from J.T. Baker, India, were used.

\subsection{Emulsion formulation}

Four biopolymers were used as wall materials for each oil species (SIHO and SIVO), and the formulations consisted of two biopolymers alone, one binary and another ternary blend. A wall material was selected for the microcapsules with a core ratio of $3: 1$, as previously described as the proportion to provide the best protection against oxidation (Carneiro et al., 2013). Biopolymer stock solutions were formed as follows: $\mathrm{MD}$ and $\mathrm{H}$ were added to distilled water according to specifications given by the provider; AG was added to distilled water and let stand overnight under stirring in order to achieve complete hydration. WPC was added to water and heated at $80^{\circ} \mathrm{C}$ for $30 \mathrm{~min}$. A binary biopolymer blend was obtained by mixing AG:MD (1:1), while a ternary blend was made by AG:MD:WPC (3:13:3).

Then, SIHO or SIVO were added by droplet into each biopolymer solution and the corresponding emulsions were formed using a Silverson L5M-A homogenizer (Silverson Machines, Inc., U.K.) at $9000 \mathrm{rpm}$ for $10 \mathrm{~min}$ at low temperature $\left(<30^{\circ} \mathrm{C}\right)$. Fresh emulsions were immediately taken to spray drying.

\subsection{Elaboration of spray dried microcapsules}

The spray drying process was performed in a laboratory scale spray dryer Büchi B-290 (Büchi Labortechnik AG, Switzerland) with a nozzle atomization system $(0.7 \mathrm{~mm}$ diameter nozzle), air flow rate of $31.5 \mathrm{~m}^{3} / \mathrm{h}$ and compressor air pressure of 50 mbar. Inlet and outlet air temperatures were $150 \pm 2$ and $70 \pm 2{ }^{\circ} \mathrm{C}$ respectively, and each emulsion was fed at a flow rate $50 \mathrm{~g} / \mathrm{min}$. The dried microcapsules were collected and stored in opaque hermetic bags at $-15^{\circ} \mathrm{C}$ until further analyses were carried out.

\subsection{Physicochemical characterization of microcapsules}

\subsubsection{Encapsulation efficiency and moisture}

Encapsulation efficiency (EE) was determined following the method described by Bae and Lee (2008) with some modifications. Thirty-five milliliters of ethyl ether were added to $2.5 \mathrm{~g}$ of microcapsules in a glass jar with a lid, which was shaken by magnetic stirring for $1 \mathrm{~min}$ at room temperature $\left(25^{\circ} \mathrm{C}\right)$ in order to extract free SIO. The solvent mixture was filtered through a Whatman filter paper $\mathrm{N}^{\circ} 1$ and the powder was rinsed with $15 \mathrm{~mL}$ of ethyl ether. Then, the solvent was evaporated under vacuum at $35^{\circ} \mathrm{C}$. Finally, the flask containing the surface oil (SO) was vacuum heated at $70{ }^{\circ} \mathrm{C}$ for $90 \mathrm{~min}$. Resultant non-encapsulated or surface SIO was weighed, and encapsulation efficiency (EE) was calculated assuming that total oil content (TO) was formed by the surface and core SIO contained within the microcapsules, and corresponding to the initial oil content added into emulsions (Eq. 1) (Jafari et al., 2008; Tonon et al., 2012).

$$
\mathrm{EE}(\%)=\frac{(\mathrm{TO}-\mathrm{SO}) * 100}{\mathrm{TO}}
$$

The moisture of the samples was determined gravimetrically by drying until constant weight. The procedure was carried out using halogen moisture analyzer KERN DBS (KERN \& SohnGmbH, Balingen, Germany) operating at $103 \pm 2{ }^{\circ} \mathrm{C}$ according to ISO/FIS 662:2015.

\subsubsection{Morphology and particle size distribution}

The particle size distribution of the microcapsules was determined by laser diffraction spectroscopy using a Mastersizer Micro (Malvern Panalytical, UK). The samples were suspended in deionized water, sonicated in a bath for two minutes and measured immediately. Volume weighed mean size or DeBroukere mean diameter $\left(\mathrm{D}_{4,3}\right)$ was determined. The morphology of the microcapsules was evaluated by means of a FEI scanning electron microscope (QUANTA 250 FEG, Hillsboro, USA). Samples were previously gold sputtered with an Edwards Sputter Coater S150B at $5 \mathrm{kV}$ (Crawley, England). 


\subsubsection{Oxidative stability and estimated shelf life}

The oxidative stability of bulk SIO and its microencapsulated form was evaluated by Differential Scanning Calorimetry (DSC) and Rancimat Test. For DSC, the Oxidation Onset Temperature (OOT) was determined with DSC Mettler 822 (Mettler Toledo, USA), where OOT is defined as a thermal jump associated with an exothermic reaction due to oil oxidation. In this case, the ASTM E2009-08 Method A, oxygen gas was used (gas flow $50 \mathrm{ml} / \mathrm{min}$; initial temperature $25^{\circ} \mathrm{C}$; final temperature $300^{\circ} \mathrm{C}$; heating speed $10^{\circ} \mathrm{C} / \mathrm{min}$ ).

The Rancimat test was used according to Velasco et al., (2000) in an 892 Professional Rancimat (Metrhom, Switzerland). Induction period (IP), defined as the time required to produce a marked increase in conductivity, was determined.

For shelf-life purpose, IP at 70, 80, 90 and $100{ }^{\circ} \mathrm{C}$ for both SIOs, bulk and microencapsulated, was determined. Air flow of $20 \mathrm{~L} / \mathrm{h}$ was stated. All determinations were made in triplicate. The extrapolation of the shelf-life for all the treatments at $25^{\circ} \mathrm{C}$ was calculated using the software for the equipment, following Eq. 2 (Villanueva et al., 2017):

$$
\text { Shelf }- \text { life }=\mathrm{A} \times \mathrm{e}^{(\mathrm{B} \times \mathrm{T})}
$$

where $\mathrm{A}$ and $\mathrm{B}$ are the regression coefficients based on IP determinations, $\mathrm{T}$ is the temperature at which induction period is calculated.

\subsubsection{Physicochemical stability of microcapsules during storage}

The microcapsules were stored at $15^{\circ} \mathrm{C}$ in aluminum bags for 120 days. Physicochemical stability was evaluated at $0 \mathrm{~d}(1), 70 \mathrm{~d}(2)$, and $120 \mathrm{~d}$ (3) of storage. Peroxide value (PV) was obtained by iodometric titration, which measures the iodine $\left(\mathrm{I}_{2}\right)$ produced from potassium iodide by the peroxides present in a fat sample (Kolanowski et al., 2004). Two grams of microcapsules or one gram of SIOs were dissolved in $25 \mathrm{~mL}$ of chloroform:glacial acetic acid $(3: 2 \mathrm{v} / \mathrm{v})$ and vortexed for a few seconds. Then, $1 \mathrm{~mL}$ of saturated potassium iodide solution was added. After 5 min under darkness, $75 \mathrm{~mL}$ distilled water were immediately added, and the titration started. The liberated $\mathrm{I}_{2}$ was titrated with $\mathrm{Na}_{2} \mathrm{~S}_{2} \mathrm{O}_{3}(0.01 \mathrm{~N})$, using a starch solution (1\%) as an indicator, until the solution became colorless (AOCS, 1996). The advantage of this method is that the chloroform helps the oil release from the inner phase.

\subsection{Statistical analysis}

Results were expressed as mean \pm standard deviation. All measurements were made in duplicate or triplicate, depending on the determination. Analysis of variance (ANOVA) was used to analyze the acquired data at a $95 \%$ significance level. Tukey's test was used as a post-hoc comparison test to identify differences among the samples at a 95\% confidence level with Statistica 8.0 (StatSoft, USA).

\section{RESULTS AND DISCUSSION}

\subsection{Encapsulation efficiency and moisture}

According to the data included in Table 1, microcapsules with EE from 61 to $93 \%$ and from 31 to $96 \%$ were obtained for SIHO and SIVO formulations, respectively. In both cases, the highest EE were obtained with modified starch $\mathrm{H}$. This was due to their great film-forming capacity, based on the modifications made on the native starch structure: the introduction of lipophilic succinic acid chains resulted in structures with good emulsifying properties, which promoted higher EE and good volatile retention (Drusch and Schwarz, 2006, Tonon et al., 2012). The lowest values of EE were obtained with the ternary mixture of wall materials (AG:MD:WPC). Carneiro et al., (2013) reported that when using WPC as wall material of microcapsules, an unfolding of the protein molecules at

TABLE 1. Encapsulation efficiency and moisture of the microencapsulated samples containing Plukenetia huayllabambana (SIHO) and Plukenetia volubilis (SIVO) oils

\begin{tabular}{lccccc}
\hline & \multicolumn{2}{c}{ Encapsulation Efficiency (\%) } & & \multicolumn{2}{c}{ Moisture (\%w/w) } \\
\cline { 2 - 3 } \cline { 5 - 6 } Formulation & SIHO & SIVO & & SIHO & SIVO \\
\hline H & $93.3 \pm 0.5^{\mathrm{b}}$ & $96.5 \pm 0.7^{\mathrm{a}}$ & & $3.20 \pm 0.03^{\mathrm{F}}$ & $2.40 \pm 0.28^{\mathrm{G}}$ \\
AG & $73.0 \pm 1.5^{\mathrm{d}}$ & $67.4 \pm 0.5^{\mathrm{e}}$ & & $5.87 \pm 0.13^{\mathrm{B}}$ & $6.36 \pm 0.05^{\mathrm{A}}$ \\
AG:MD & $75.8 \pm 0.9^{\mathrm{C}}$ & $67.9 \pm 0.5^{\mathrm{e}}$ & & $5.01 \pm 0.09^{\mathrm{C}}$ & $4.63 \pm 0.04^{\mathrm{D}}$ \\
AG:MD:WPC & $61.1 \pm 0.6^{\mathrm{f}}$ & $61.7 \pm 0.6^{\mathrm{f}}$ & & $3.58 \pm 0.09^{\mathrm{E}}$ & $3.34 \pm 0.24^{\mathrm{E}}$ \\
\hline
\end{tabular}

Results are expressed as means $\pm \mathrm{SD}(\mathrm{n}=3)$. Different superscript letters in each determination (lower case for Encapsulation Efficiency and capital for moisture) means significant differences $(p<0.05)$. Formulations: H: HiCap; AG: Arabic gum; AG:MD: Arabic gum+Maltodextrin; AG:MD:WPC: Arabic gum+Maltodextrin+Whey Protein Concentrate. 
the droplet's surface would enhance protein-protein interaction, leading to flocculation during emulsification and consequently reducing the emulsion stability. Then, according to Barbosa et al., (2005), the more stable the emulsion, the higher the encapsulation efficiency is, i.e., the lower the amount of nonencapsulated material on particle's surface. This protein unfolding can be attributed to, for example, not reaching the correct temperature to achieve protein denaturation during its hydration.

The moisture of the microcapsules, was found to be in the range from 3.20 to $5.87 \%$ for SIHO samples and from 2.40 to $6.36 \%$ for SIVO samples (Table 1). For both oils, the lower humidity values corresponded to the encapsulation with $\mathrm{H}$ and the higher values to the microcapsules with AG. This is consistent with the results obtained by Frascareli et al., (2012), where microcapsules produced with GA showed the highest moisture content, probably due to its high hygroscopicity, because it has many hydrophilic ramifications, which promote higher water adsorption from the ambient air. Otherwise, microcapsules produced with modified starch had the lowest moisture content values.

According to Klinkersorn et al., (2005), the desired moisture content is $3-4 \%$ for shelf-stable dried powders in the food industry. In this case, with the exception of the formulation with $A G$, all the microcapsules obtained were within the recommended moisture range.

\subsection{Particle size distribution and morphology}

According to the particle size distribution (Table 2), the $\mathrm{D}_{4,3}$ of microcapsules were between 2.6 and $6.1 \mu \mathrm{m}$ for SIHO and 2.3 and $9.8 \mu \mathrm{m}$ for
SIVO, with the highest value for the ternary mixture of wall material (AG:MD:WPC) for both oils, which is typical of particles produced by spray drying (Tonon et al., 2012).

The morphological analysis performed by SEM showed well-defined and low agglomeration microcapsules for both SIOs (Figures 1 and 2), although the majority of the population was represented by collapsed structures. This was an expected behavior for samples obtained by spray drying. Figure 2a) shows how the droplets of SIOs were homogeneously distributed in the wall matrix (Partanen et al., 2008, Wang et al., 2006).

\subsection{Oxidative stability and shelf-life}

For oxidative stability, the highest values for OOT (Table 3) were obtained for the microcapsules formulated with $\mathrm{H}$ as wall material for both ecotype oils, followed by those elaborated with the ternary mixture of wall material (AG:MD:WPC), and then those elaborated with AG and the binary mixture AG:MD. In this case, there was a notorious difference between the oxidative stability of microcapsules made of $\mathrm{H}$ and the other formulations, which demonstrated similar values.

According to Jin et al., (2018), $\mathrm{H}$ as wall material showed the best performance on surface oil, flavor retention, and oxidation resistance, demonstrating advantages even in high-load flavor systems over other ingredients such as Arabic gum. Moreover, the main difference between $\mathrm{AG}, \mathrm{AG}: \mathrm{MD}$ and AG:MD:WPC formulations is the incorporation of WPC. Based on research, whey proteins and their hydrolysates have antioxidant activity (Salami et al., 2010; Dryakova et al., 2010; Gad et al., 2011). So, the

TABLE 2. D [4,3] values obtained from microencapsulated Plukenetia huayllabambana (SIHO) and Plukenetia volubilis (SIVO) oils

\begin{tabular}{llccccc}
\hline & & & & \multicolumn{3}{c}{ Volume distribution, $\boldsymbol{\mu m}$} \\
\cline { 5 - 6 } Sacha Inchi oils & Formulation & $\mathbf{D}[\mathbf{4 , 3}] \boldsymbol{\mu m}$ & Span & $\mathbf{D}(\mathbf{v}, \mathbf{0 . 1})$ & $\mathbf{D}(\mathbf{v}, \mathbf{0 . 5})$ & $\mathbf{D}(\mathbf{v}, \mathbf{0 . 9})$ \\
\hline SIHO & H & $2.7(0.3)$ & $2.4(0.1)$ & $0.4(0.1)$ & $0.7(0.1)$ & $2.0(0.1)$ \\
& AG & $2.6(0.1)$ & $2.0(0.1)$ & $0.8(0.1)$ & $2.1(0.1)$ & $5.1(0.1)$ \\
& AG:MD & $2.9(0.4)$ & $2.3(0.3)$ & $0.8(0.1)$ & $2.2(0.2)$ & $5.8(1.1)$ \\
SIVO & AG:MD:WPC & $6.1(1.9)$ & $2.9(0.1)$ & $0.9(0.1)$ & $3.2(0.1)$ & $10.1(0.1)$ \\
& H & $2.6(1.9)$ & $1.3(0.6)$ & $0.4(0.1)$ & $0.6(0.1)$ & $1.2(0.4)$ \\
& AG & $2.4(0.1)$ & $1.7(0.1)$ & $0.8(0.1)$ & $2.0(0.1)$ & $4.3(0.1)$ \\
& AG:MD & $2.3(0.4)$ & $1.9(0.4)$ & $0.7(0.1)$ & $1.9(0.2)$ & $4.3(1.1)$ \\
& AG:MD:WPC & $9.8(1.1)$ & $6.4(1.8)$ & $0.8(0.1)$ & $2.6(0.5)$ & $18.2(7.8)$ \\
\hline
\end{tabular}

The results correspond to the average $(\mathrm{n}=3)$ and standard deviation indicated in parentheses.

$D[4,3] \mu m$ : volume weight mean size.

$D(v, 0.1)$ : particle size for which $10 \%$ of the sample is less than that limit.

$D(v, 0.5)$ : particle size for which $50 \%$ of the sample is less than that limit.

$D(v, 0.9)$ : particle size for which $90 \%$ of the sample is less than that limit.

Span: dispersion index.

Formulations: H: HI-CAP ${ }^{\circledR}$-100; AG: Arabic gum; AG:MD: Arabic gum+Maltodextrin; AG:MD:WPC: Arabic gum+ Maltodextrin+Whey Protein Concentrate. 

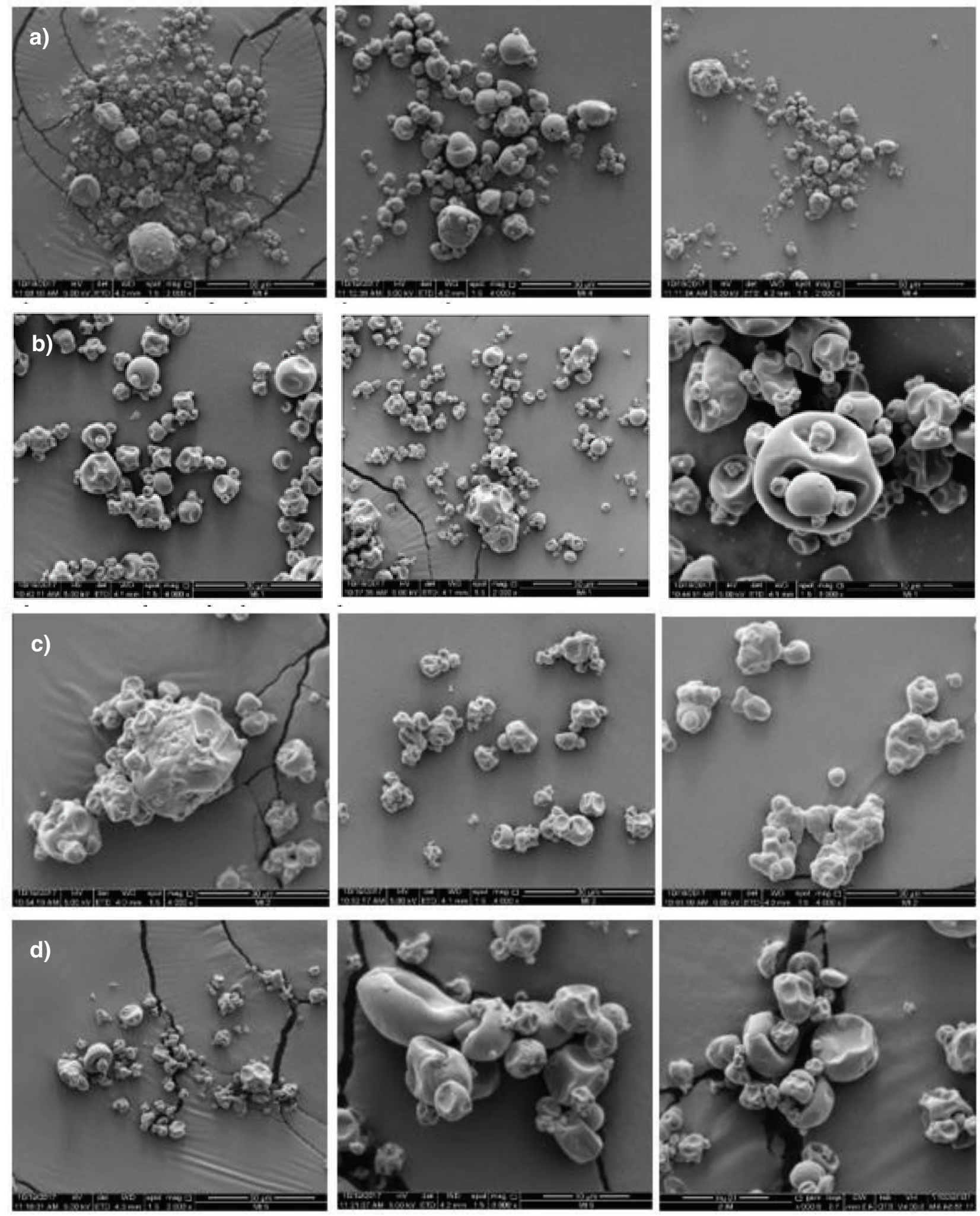

FIGURE 1. SEM micrographs from microencapsulated $P$. Huayllabambana oil (SIHO).

a): $\mathrm{SIHO}+\mathrm{HI}-\mathrm{CAP}^{\mathbb{R}}-100$; b): $\mathrm{SIHO}+$ Arabic gum; c): SIHO+Arabic gum+Maltodextrin; d): SIHO+Arabic gum+Maltodextrin+Whey Protein Concentrate. 

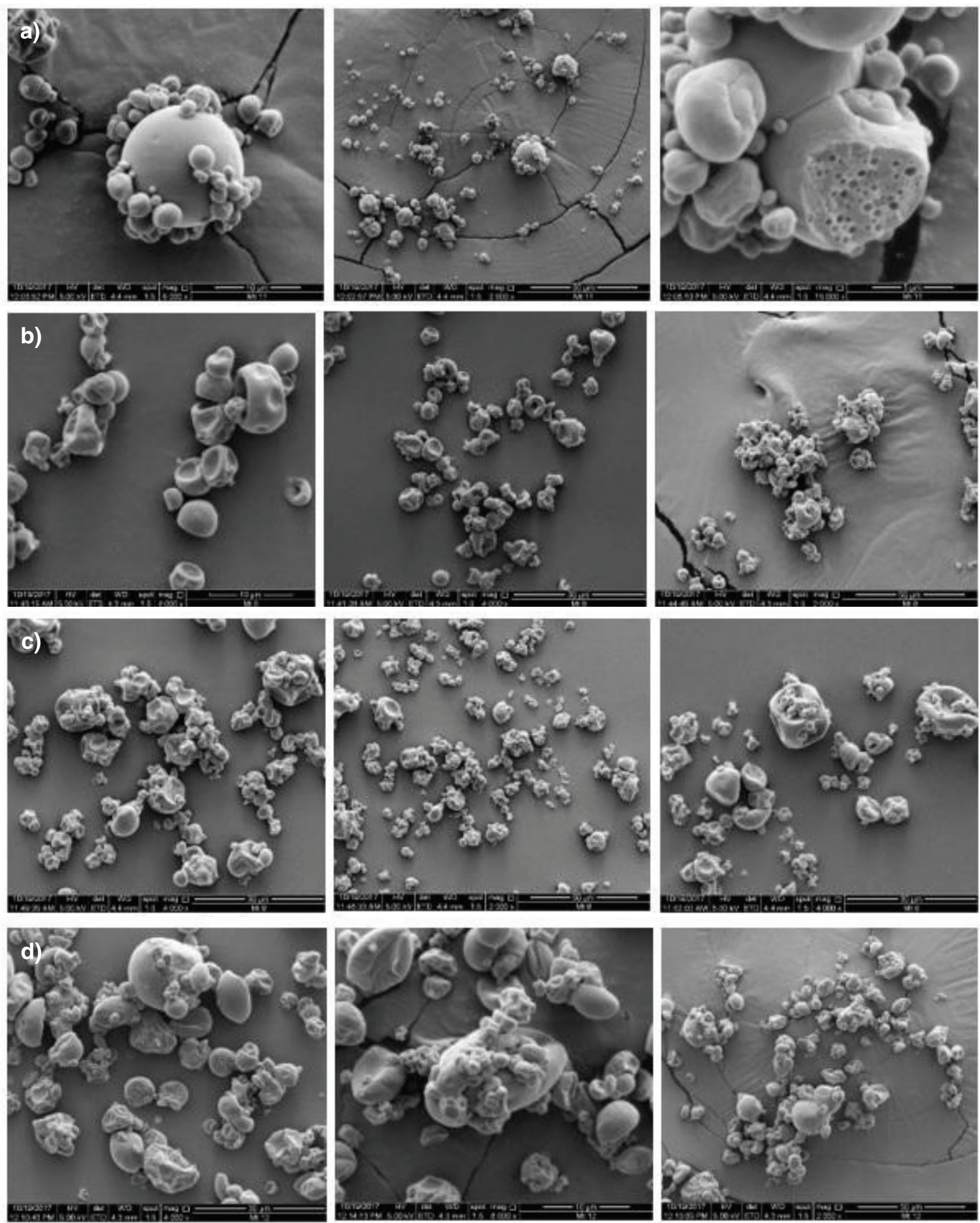

FIGURE 2. SEM micrographs from microencapsulated $P$. Volubilis oil (SIVO). a): SIVO+ HI-CAP ${ }^{\mathbb{Q}}-100$; b): SIVO+Arabic gum; c): SIVO+Arabic gum+Maltodextrin; d): SIVO+Arabic gum+Maltodextrin+Whey Protein Concentrate. 
TABle 3. Oxidation Onset Temperature (OOT) obtained from microencapsulated Plukenetia huayllabambana (SIHO) and Plukenetia volubilis (SIVO) oils

\begin{tabular}{lccccc}
\hline & \multicolumn{2}{c}{ SIHO } & & \multicolumn{2}{c}{ SIVO } \\
\cline { 2 - 3 } Wall material & OOT $\left({ }^{\circ} \mathbf{C}\right)$ & $\mathbf{U}$ & & OOT $\left({ }^{\circ} \mathbf{C}\right)$ & $\mathbf{U}$ \\
\hline H & $223 \pm 0.5$ & 13 & & $224 \pm 0.4$ & 13 \\
AG & $173 \pm 0.2$ & 10 & & $182 \pm 0.6$ & 11 \\
AG:MD & $173 \pm 0.4$ & 10 & & $179 \pm 0.1$ & 10 \\
AG:MD:WPC & $181 \pm 0.4$ & 10 & & $187 \pm 0.3$ & 11 \\
SIHO & $169 \pm 2.0$ & 10 & & $174 \pm 0.3$ & 10 \\
\hline
\end{tabular}

$U$ : expanded uncertainty for the OOT test.

"The reported expanded measurement uncertainty was calculated by multiplying the combined standard uncertainty by a coverage factor $k=2$, which corresponds to an approximate level of $95 \%$ confidence under normal distribution.

Formulations: H: HI-CAP ${ }^{\circledR}-100$; AG: Arabic gum; AG:MD: Arabic gum+Maltodextrin; AG:MD:WPC: Arabic gum+ Maltodextrin+Whey Protein Concentrate. use of WPC may have contributed to retarding the lipid oxidation of microencapsulated SIO, being a reason for the better oxidative stability and shelf-life shown by samples microencapsulated with this wall material. Those data are in agreement with those shown in Table 4, were IP was determined and the shelf life at $25^{\circ} \mathrm{C}$ was calculated by extrapolation.

\subsection{Physicochemical stability of microcapsules during storage}

Table 5 shows oxidation patterns during the storage of microencapsulated SIO for both ecotypes and for 120 days. Immediately after the spray drying process, no increase in lipid oxidation products was found in any of the samples in relation to their original oils (medium values $=2 \mathrm{meqO}_{2} / \mathrm{kg}$ oil). The data was in agreement with the requirement of the

TABLE 4. Induction Period (IP) and shelf-life obtained from microencapsulated Plukenetia huayllabambana (SIHO) and Plukenetia volubilis (SIVO) oils

\begin{tabular}{|c|c|c|c|c|c|c|}
\hline \multirow{3}{*}{$\begin{array}{l}\text { Sacha Inchi } \\
\text { oils }\end{array}$} & \multirow[b]{3}{*}{ Wall material } & \multicolumn{4}{|c|}{ IP (hours) } & \multirow{3}{*}{$\begin{array}{c}\text { Extrapolated } \\
\text { shelf-life at } \\
25^{\circ} \mathrm{C} \text { (days) }\end{array}$} \\
\hline & & \multicolumn{4}{|c|}{ Temperature $\left({ }^{\circ} \mathrm{C}\right)$} & \\
\hline & & 70 & 80 & 90 & 100 & \\
\hline \multirow[t]{5}{*}{ SIHO } & $\mathrm{H}$ & $82.75 \pm 0.74$ & $34.08 \pm 0.70$ & $17.11 \pm 0.40$ & $8.66 \pm 0.14$ & $93.0 \pm 2.6^{\mathrm{b}}$ \\
\hline & $\mathrm{AG}$ & $31.10 \pm 1.09$ & $13.86 \pm 1.20$ & $4.94 \pm 0.47$ & $2.48 \pm 0.29$ & $62.8 \pm 7.2^{\mathrm{ef}}$ \\
\hline & AG:MD & $33.26 \pm 4.85$ & $14.13 \pm 0.16$ & $5.64 \pm 0.15$ & $2.90 \pm 0.06$ & $60.7 \pm 1.8^{\mathrm{f}}$ \\
\hline & AG:MD:WPC & $62.14 \pm 3.23$ & $27.72 \pm 0.96$ & $14.22 \pm 0.70$ & $6.81 \pm 0.12$ & $67.3 \pm 2.7^{\mathrm{e}}$ \\
\hline & Initial SIHO & $35.90 \pm 2.34$ & $11.84 \pm 0.48$ & $5.64 \pm 0.15$ & $2.90 \pm 0.06$ & $49.0 \pm 5.7^{\mathrm{g}}$ \\
\hline \multirow[t]{5}{*}{ SIVO } & $\mathrm{H}$ & $95.32 \pm 2.48$ & $40.31 \pm 1.27$ & $18.36 \pm 0.36$ & $8.89 \pm 0.29$ & $144.3 \pm 10.6^{\mathrm{a}}$ \\
\hline & AG & $78.00 \pm 1.57$ & $38.61 \pm 1.49$ & $18.70 \pm 0.61$ & $9.26 \pm 0.17$ & $79.9 \pm 2.0^{\mathrm{d}}$ \\
\hline & AG:MD & $74.53 \pm 0.99$ & $32.06 \pm 0.40$ & $16.41 \pm 0.33$ & $8.18 \pm 0.11$ & $79.0 \pm 3.3^{\mathrm{d}}$ \\
\hline & AG:MD:WPC & $84.62 \pm 2.95$ & $37.65 \pm 0.90$ & $18.66 \pm 0.25$ & $9.70 \pm 0.15$ & $84.1 \pm 0.7^{\mathrm{c}}$ \\
\hline & Initial SIVO & $41.76 \pm 6.31$ & $19.38 \pm 2.93$ & $9.23 \pm 0.28$ & $4.60 \pm 0.35$ & $46.0 \pm 4.3^{\mathrm{g}}$ \\
\hline
\end{tabular}

Results are expressed as means \pm standard deviation $(n=3)$. For the extrapolated shelf-life at $25^{\circ} \mathrm{C}$, the different superscript letter means significant differences $(\mathrm{p}<0.05)$. Formulations: H: HI-CAP ${ }^{\mathbb{B}}-100$; AG: Arabic gum; AG:MD: Arabic gum+Maltodextrin; AG:MD:WPC: Arabic gum+Maltodextrin+Whey Protein Concentrate.

TABle 5. Peroxide value ( $\mathrm{meqO}_{2} / \mathrm{kg}$ oil) obtained from microencapsulated Plukenetia huayllabambana (SIHO) and Plukenetia volubilis (SIVO) oils during storage time (0,90 and 120 days)

\begin{tabular}{|c|c|c|c|c|c|c|}
\hline \multirow[b]{4}{*}{ Wall material } & \multicolumn{6}{|c|}{$\mathrm{PV}\left(\mathrm{meqO}_{2} / \mathrm{kg}\right.$ oil) } \\
\hline & \multicolumn{3}{|c|}{ SIHO } & \multicolumn{3}{|c|}{ SIVO } \\
\hline & \multicolumn{3}{|c|}{ Days } & \multicolumn{3}{|c|}{ Days } \\
\hline & $\mathbf{0}$ & 70 & 120 & $\mathbf{0}$ & 70 & 120 \\
\hline $\mathrm{H}$ & $0.00 \pm 0.00$ & $0.46 \pm 0.03$ & $5.51 \pm 0.01^{\mathrm{e}}$ & $0.00 \pm 0.00$ & $0.26 \pm 0.00$ & $4.15 \pm 0.00^{f}$ \\
\hline$A G$ & $2.89 \pm 0.01$ & $5.87 \pm 0.03$ & $10.26 \pm 0.02^{\mathrm{b}}$ & $2.99 \pm 0.01$ & $4.30 \pm 0.03$ & $9.12 \pm 0.02^{\mathrm{c}}$ \\
\hline AG:MD & $2.91 \pm 0.01$ & $6.53 \pm 0.07$ & $10.75 \pm 0.01^{\mathrm{a}}$ & $3.69 \pm 0.02$ & $5.45 \pm 0.03$ & $9.13 \pm 0.04^{\mathrm{c}}$ \\
\hline AG:MD:WPC & $2.28 \pm 0.03$ & $4.84 \pm 0.02$ & $9.12 \pm 0.03^{\mathrm{c}}$ & $2.16 \pm 0.01$ & $3.24 \pm 0.02$ & $7.98 \pm 0.03^{\mathrm{d}}$ \\
\hline
\end{tabular}

Results are expressed as means \pm standard deviation $(n=3)$. For 120 days of storage, different superscript letter means significant differences $(\mathrm{p}<0.05)$.

Formulations: H: HI-CAP ${ }^{\circledR}-100$; AG: Arabic gum; AG:MD: Arabic gum+Maltodextrin; AG:MD:WPC: Arabic gum + Maltodextrin+Whey Protein Concentrate. 
technical regulation of Peru (NTP, 2014) for SIHO and SIVO ecotypes, where no more than $10 \mathrm{meq}$ $\mathrm{O}_{2} / \mathrm{kg}$ of oil are required.

After 70 days of storage, the PV for all the samples was inside the NTP in contrast to the non-encapsulated oils, which exceeded the value recommended before the first sampling date. A significant increment in PV values was observed after 120 days. It was observed that using $\mathrm{H}$ and the ternary blend (AG:MD:WPC) as wall material, for both SIO varieties, the PV remains within the limits established in the regulations. Also, for the microcapsules formulated with $A G$ and the binary blend (AG:MD), for SIVO, the PVs are within the values established in the regulation, but not for SIHO.

Significant differences were found among all the samples, thus highlighting the greater protection of $\mathrm{H}$ in both oils. Also, in both cases and with significant differences with respect to the other formulations, the binary mixture (A:MD) proved to be the one that exerted the least protection against oxidation over the storage time up to 120 days.

Based on these results, it can be seen that the same trend is maintained with respect to that obtained in terms of oxidative stability and shelf-life, with the $\mathrm{H}$ formulation being the sample with the better performance for both oils.

\section{CONCLUSIONS}

Microcapsules with EEs between 60 and 90\% were obtained, showing the highest value for the $\mathrm{H}$ formulation in both SIOs assayed. The moisture of the microcapsules was lower than $6 \%$ in all cases.

For both powders, the lowest humidity values corresponded to the encapsulation with $\mathrm{H}$ and the highest value was found with AG.

In relation to the particle size determination, it was shown that all the analyzed samples had an average diameter smaller than $10 \mu \mathrm{m}$, with the ternary mixture (AG:MD:WPC) being the highest for each ecotype. The morphological analysis performed by SEM showed that all samples had well defined spherical forms with low agglomeration. Nevertheless, the majority of the population was represented by collapsed structures, which was expected for microcapsules obtained by spray drying.

Regarding the analysis of the OOT, shelf-life and PV during the storage of the microcapsules, it was concluded that the different wall materials selected showed similar behavior in both species of SIOs. The order of protection against oxidation was the following for both SIO species: SIO + AG:MD < $\mathrm{SIO}+\mathrm{AG}<\mathrm{SIO}+\mathrm{AG}: \mathrm{MD}: \mathrm{WPC}<\mathrm{SIO}+\mathrm{H}$.

Based on the results it can be concluded that the SIOs microcapsules produced can be recommended as a functional ingredient in the food industry and health sector.
Conflict of interest. This article represents the authors' own work. We are not aware of any conflict of interest.

\section{ACKNOWLEDGEMENTS}

This work was funded by the National Program of Agricultural Innovation (PNIA), Ministry of Agriculture and Irrigation-Peru, World Bank (Project: 020-2015-PNIA/UPMSI/IE) and Lima University, Peru.

\section{REFERENCES}

Aberkane L, Roudaut G, Saurel R. 2014. Encapsulation and Oxidative Stability of PUFA-Rich Oil Microencapsulated by Spray Drying Using Pea Protein and Pectin. Food Bioproc. Technol.7. 1505. https://doi.org/10.1007/s11947-013-1202-9

AOCS Official Method Cd 8b-90.1996. Peroxide Value, Acetic Acid-Isooctane Method. In Official Methods and Recommended Practices of the American Oil Chemists' Society; AOCS Press: Champaign, IL.

Bae EK, Lee SJ. 2008. Microencapsulation of avocado oil by spray drying using whey protein and maltodextrin. J. Microencapsulation 25 (8), 549-560. https://doi.org/ $10.1080 / 02652040802075682$

Barbosa MIMJ, Borsarelli CD, Mercadante AZ. 2005. Light stability of spray dried bixin encapsulated with different edible polysaccharide preparations. Food Res. Internat. 38 (8-9), 989-994. https://doi.org/10.1016/j.foodres.2005.02.018

Barceló-Coblijn G, Murphy EJ. 2009. Alpha-linolenic acid and its conversion to longer chain $n$-3 fatty acids: benefits for human health and a role in maintaining tissue $n-3$ fatty acid levels. Prog. Lipid Res. 48 (6), 355-374. https://doi. org/10.1016/j.plipres.2009.07.002

Campos D, Chirinos R, Gálvez L, Pedreschi R. 2018. Bioactive potential of Andean fruits, seeds, and tubers. Adv. Food Nutrit. Res. 84, 287-343. https://doi.org/10.1016/bs.afnr. 2017.12.005

Carneiro HCF, Tonon RV, Grosso CRF, Hubinger MD. 2013. Encapsulation efficiency and oxidative stability of flaxseed oil microencapsulated by spray drying using different combinations of wall materials. J. Food Eng. 115 (4), 443-451. https://doi.org/10.1016/j.jfoodeng.2012.03.033

Chasquibol NA, Del Aguila C, Yácono JC, Guinda Á, Moreda W, Gómez-Coca RB, Pérez-Camino MC. 2014. Characterization of glyceridic and unsaponifiable compounds of Sacha inchi (Plukenetia huayllabambana L.) oils. J. Agric. Food Chem. 62, 10162-10169. https://doi.org/ $10.1021 /$ jf5028697

Cholewski M, Tomczkowa M, Tomczyk M. 2018. A Comprehensive Review of Chemistry, Sources and Bioavailability of Omega-3 Fatty Acids. Nutrients 10 (11), 1662. https://doi. org/10.3390/nu10111662

Delgado-Lista J, Pérez-Martinez P, López-Miranda J, PérezJiménez F. 2012. Long chain omega-3 fatty acids and cardiovascular disease: a systematic review. British J. Nutrit. 107 (Suppl 2), S201-13. https://doi.org/10.1017/ S0007114512001596

Drusch S, Schwarz K. 2006. Microencapsulation properties of two different types of n-octenylsuccinate-derivatised starch. Eur. Food Res. Technol. 222 (1-2), 155-164. https:// doi.org/10.1007/s00217-005-0020-3

Dryakova A, Pihlanto A, Marnila P, Curda L, Korhonen HJT. 2010. Antioxidant properties of whey protein hydrolysates as measured by three methods. Eur. Food Res. Technol. 230 (6), 865-874. https://doi.org/10.1007/s00217-010-1231-9

Gabas AL, Telis VRN, Sobral PJA, Telis-Romero J. 2007. Effect of maltodextrin and arabic gum in water vapor sorption thermodynamic properties of vacuum dried pineapple pulp powder. J. Food Eng. 82 (2), 246-252. https://doi.org/ 10.1016/j.jfoodeng.2007.02.029 
Gad AS, Khadrawy YA, El-Nekeety AA, Mohamed SR, Hassan NS, Abdel-Wahhab MA. 2011. Antioxidant activity and hepatoprotective effects of whey protein and Spirulina in rats. Nutrition 27 (5), 582-589. https://doi.org/10.1016/j. nut. 2010.04 .002

Gallardo G, Guida L, Martinez V, López MC, Bernhardt D, Blasco R, Hermida L. 2013. Microencapsulation of linseed oil by spray drying for functional food application. Food Research International 52, (473-482). https://doi. org/10.1016/j.foodres.2013.01.020

Gharsallaoui AR, Roudaut G, Chambin O, Voilley A, Saurel R. 2007. Applications of spray drying in microencapsulation of food ingredients: an overview. Food Res. Int. 40 (9), 1107-1121. https://doi.org/10.1016/j.foodres.2007.07.004

Goud KG, Park HJ. 2005. Recent Developments in Microencapsulation of Food Ingredients. Drying Technol. 23, 1361-1394. https://doi.org/10.1081/DRT-200063478

Frascareli EC, Silva VM, Tonon RV, Hubinger MD. 2012. Effect of process conditions on the microencapsulation of coffee oil by spray drying. Food Bioprod. Process. 90 (3), 413-424. https://doi.org/10.1016/j.fbp.2011.12.002

Hoseini A, Jafari SM, Mirzaei H, Akhavan S. 2015. Application of image processing to assess emulsion stability and emulsification properties of Arabic gum. Carbohydr. Polym. 126, 1-8. https://doi.org/10.1016/j.carbpol.2015.03.020

ISO. 662:2016. Animal and vegetable fats and oils - Determination of moisture and volatile matter content

Jafari SA, Assadpoor E, He Y, Bhandari B. 2008. Encapsulation efficiency of food flavours and oils during spray drying. Drying Technol. 26 (7), 816-835. https://doi.org/10.1080/ 07373930802135972

Jin YL. 2018. Chapter 17 - Starch-Based Microencapsulation. Starch in Food (Second Edition), Pag. 661-690.

Klinkersorn U, Sophanodora P, Chinachoti P, McClements D, Decker EA. 2005. Stability of spray-dried tuna oil emulsion encapsulated with two-layered interfacial membranes. J. Agric. Food Chem. 53, 8365-8371. https://doi. org/10.1021/jf050761r

Kolanowski W, Laufenberg G, Kunz B. 2004. Fish oil stabilization by microencapsulation with modified cellulose. Int. J. Food Sci. Nutrit. 55 (4), 333-343. https://doi.org/10.1080/0 9637480410001725157

NTP. Norma Tećnica Peruana 151.400, amendment to NTP 151.400, 2009. Requisitos Aceite Sacha Inchi, INDECOPI: Lima, Perú, 2014.

Partanen R, Raula J, Seppänen R, Buchert J, Kauppinen E, Forssell P. 2008. Effect of relative humidity on oxidation of flaxseed oil in spray dried whey protein emulsions. J. Agric. Food Chem. 56 (14), 5717-5722. https://doi.org/10.1021/ jf8005849

Rodríguez A, Corazón GM, Cachique D, Mejía K, Del Castillo D, Renno J F, García-Dávila C. 2010. Diferenciación morfológica y por ISSR (Inter simple sequence repeats) de especies del género Plukenetia (Euphorbiaceae) de la Amazonia peruana: propuesta de una nueva especie. Revistas Peruana de biología v.17 n.3. Lima dic. 201 O. versión Online ISSN 1727-9933. https://doi.org/10.15381/rpb.v17i3.7

Salami M, Moosavi-Movahedi AA, Ehsani MR, Yousefi R, Haertlé T, Chober JM, Razavi SH, Henrich R, Balalaie S, Ebadi SA, Pourtakdoost S, Niasari-Naslaji A. 2010. Improvement of the antimicrobial and antioxidant activities of camel and bovine whey proteins by limited proteolysis. J. Agric. Food Chem. 58 (6), 3297-3302. https://doi. org/10.1021/jf9033283

Silva P, Stringheta P, Teófilo R, de Oliveira I. 2013. Parameter optimization for spray-drying microencapsulation of jaboticaba (Myrciaria jaboticaba) peel extracts using simultaneous analysis of responses. Journal of Food Engineering 117, 538-544. https://doi.org/10.1016/j.jfoodeng.2012.08.039

Tonon RB, Pedro RB, Grosso C, Hubinger MD, 2012. Microencapsulation of Flaxseed Oil by Spray Drying: Effect of Oil Load and Type of Wall Material. Drying Technol. Int. J. 30 (13), 1491-1501. https://doi.org/10.108 $0 / 07373937.2012 .696227$

Triana-Maldonado DM, Torijano-Gutiérrez SA, GiraldoEstrada C. 2017. Supercritical $\mathrm{CO}_{2}$ extraction of oil and omega-3 concentrate from Sacha inchi (Plukenetia volubilis L.) from Antioquia, Colombia. Grasas Aceites 68 (1), e172. https://doi.org/10.3989/gya.0786161

Velasco J, Dobarganes MC, Márquez-Ruiz G. 2000. Application of the accelerated test Rancimat to evaluate oxidative stability of dried microencapsulated oils. Grasas Aceites 51 (4), 261-267. https://doi.org/10.3989/gya.2000.v51.i4.422

Villanueva E, Rodríguez G, Aguirre E, Castro V. 2017. Influence of antioxidants on oxidative stability of the oil Chia (Salvia hispanica L.) by rancimat. Scientia Agropecuaria 8 (1), 19-27

Wang C, Harris WS, Chung M, Lichtenstein AH, Balk EM, Kupelnick B, Jordan HS, Lau J. 2006. n-3 fatty acids from fish or fish-oil supplements, but not alpha-linolenic acid, benefit cardiovascular disease outcomes in primaryand secondary-prevention studies: A systematic review. Am. J. Clin. Nutrit. 84 (1), 5-17. https://doi.org/10.1093/ $\mathrm{ajcn} / 84.1 .5$ 